\title{
インフルエンザウイルスのゲノムパッケージング機構
}

\author{
野田岳志
}

\section{Genome Packaging Mechanism of Influenza A Virus}

\author{
Takeshi Noda \\ Division of Ultrastructural Virology, International Research Center for Infectious Diseases, Institute of \\ Medical Science, University of Tokyo; 4-6-1 Shirokanedai, Minato-ku, Tokyo 108-8639, Japan.
}

(Received May 21, 2015)

\begin{abstract}
The influenza A virus genome consists of eight-segmented, single-stranded, negative-sense RNAs. Each genomic viral RNA segment (vRNA) encodes different viral proteins that are necessary for efficient virus replication, and forms a ribonucleoprotein complex (RNP) together with viral nucleoproteins and an RNA polymerase complex. Later in infection, progeny virions, which are released from the plasma membrane of the infected cell, must incorporate the eight separate vRNAs to be infectious. However, the mechanism by which the segmented vRNAs are incorporated into each progeny virion remains unclear. To elucidate the genome packaging mechanism of influenza A virus, we examined the architecture of RNPs within progeny virions using several electron microscopic analyses. We demonstrated that each progeny virion incorporates eight RNPs arranged in a specific pattern, in which seven RNPs surround the central one. Such characteristic arrangement is found in all influenza A virus strains tested here, suggesting that the mechanism by which well-organized eight RNPs is incorporated into virion is common to influenza A viruses. In addition, there seem to be physical interactions among the eight RNPs via nucleic acid-like structures, suggesting that there are specific interactions among the eight vRNAs in the form of RNPs. These results indicate that influenza A virion selectively packages a complete set of eight separate vRNAs.
\end{abstract}

Key words__ influenza A virus; genome packaging; electron microscopic analysis

\section{1. はじめに}

A 型インフルエンザウイルスは 8 分節のマイナ ス鎖 RNA をゲノムとして持つ. 感染細胞から子孫 ウイルスが形成される際，分節化されたゲノムはど のようにウイルス粒子内に取り込まれるのか? こ の単純な疑問は, 半世紀以上もの間, ウイルス研究 者を悩ませてきた。 ここでは，われわれがこれまで に得た知見を基に，ゲノムパッケージング機構につ いて概説したい.

2. $\mathbf{A}$ 型インフルエンザウイルスゲノム

A 型インフルエンザウイルスのゲノム RNA は, 8 本に分節化されている。 各 RNA 分節（890 塩基 から 2341 塩基）にはウイルスが細胞で効率よく増

東京大学医科学研究所感染症国際研究センター微細構 造ウイルス学分野（干108-8639 東京都港区白金台 4-61)

e-mail: t-noda@ims.u-tokyo.ac.jp

本総説は, 日本薬学会第 134 年会シンポジウム S11 で 発表した内容を中心に記述したものである.
殖するために必須のタンパク質がそれぞれコードさ れている。ゲノム RNA は, 核タンパク質 (nucleoprotein; NP) と 3 種類の RNA 依存性 RNA ポリメラーゼサブユニット（PB2, PB1, PA） とと もに ribonucleoprotein complex (RNP) を形成する.

RNP はゲノム RNA の転写・複製を担うゲノムータ ンパク質複合体である. インフルエンザウイルス は，標的細胞表面にあるレセプターに結合すること で感染を開始する。ウイルス粒子はエンドサイトー シスによって細胞内に侵入し，エンドソーム膜と融 合後, RNPを細胞質内に放出する。放出された RNP は核内に輸送され，そこでゲノム RNAの転 写・複製が行われる。複製されたゲノム RNA は新 たに合成された NPや RNA ポリメラーゼサブユ ニットとともに RNP を形成し，これらは核膜孔を 通過して, 出芽の場となる細胞表面へと輸送され る. 輸送された RNP は他のウイルス構造タンパク 質とともに脂質二重膜（エンベロープ）を被り，ウ イルス粒子となって細胞外に放出される. 


\section{3. パッケージング仮説}

ゲノムパッケージングメカニズムに関しては，2 つの仮説が立てられていた。1つはランダムパッ ケージング説で，ウイルス粒子内に取り込まれる RNP の数も種類もバラバラというものである.こ の仮説は，8 種類の RNP にはその取り込みに関与 する共通の目印があり，その目印を持つ RNP は区 別されることなく取り込まれるため, 結果としてウ イルス粒子によって取り込まれる RNP の数と種類 が異なるというものである。つまり，RNP を7 本 以下しか取り込まない粒子もあれば，9本以上取り 込む粒子もあるが， 8 種類の RNP すべてを取り込 んだウイルス粒子だけが増殖能を獲得するという仮 説である．増殖能を持つインフルエンザウイルス粒 子は, 細胞外に放出されたウイルス粒子の 10 分の 1 程度しかないということが古くから知られてお り, 1) また，9 本以上の RNA 分節を取り込むことが 可能であるという報告もあったことから, 2) ゲノム RNA はランダムに取り込まれるという仮説が唱え られてきた。もも 1 つの仮説は選択的パッケージン グ説である，この仮説では，それぞれの RNP に独 自の目印が存在しており，ゲノムパッケージングの 際にはその目印によって個々の RNP が区別され， 8 種類の RNP が選択的にウイルス粒子内に取り込 まれると予想されている．しかしいずれの仮説につ いても，それを支持する直接的な証拠は得られてい なかった.

\section{4. 選択的ゲノムパッケージング}

プラスミド cDNA から人工的にインフルエンザ ウイルスを合成するリバースジェネティクス法3)を 用いて以下のような実験を行い，各 RNA 分節のウ イルス粒子内への取り込みに特異的な遺伝子配列, すなわちゲノムパッケージングの際に各 RNA 分節 に「独自の目印」が存在することを見い出した．

はじめに，NA 分節（Neuraminidase をコードす る遺伝子分節）を用いて，様々な欠損領域を持つ変 異 NA 分節シリーズを作製した. ${ }^{4}$ ) 変異 NA 分節と ともに, 他の 7 種類 (PB2, PB1, PA, HA, NP, M, NS）の遺伝子分節を用いてウイルスを人工合成し, どの変異 NA 分節がウイルス粒子内に取り込まれ 易く, ぞの変異 NA 分節が取り込まれ難いのかを 調べた。その結果，NA 遺伝子の翻訳領域の両末端 に，NA 分節がウイルス粒子内に効率よく取り込ま
れるために重要な領域（パッケージングシグナル配 列）が存在することが明らかになった．同様に，他 の 7 種類の遺伝子分節においても，翻訳領域の両末 端にパッケージングシグナルが見つかつた. ${ }^{5-7)}$ 翻 訳領域の塩基配列は各遺伝子分節で異なることから, 8 本の遺伝子分節はそれぞれ独自の目印を持ってい たと言える.

続いて，以下のように RNP を取り込みつつある 出芽ウイルス粒子を電子顕微鏡解析し，ウイルス粒 子 RNP の視覚化を試みた。 ${ }^{8)}$ ウイルスを細胞に感 染させ, 10 時間後, 細胞表面から出芽するウイル ス粒子を異なる 2 方向から観察した。出芽ウイルス 粒子の縦断面を観察すると， ウイルス粒子内には太 さ約 $13 \mathrm{~nm}$ の数本の $\operatorname{rod}$ が含まれている様子が観 察された。これらはウイルス粒子の出芽方向と平行 に, ウイルス粒子の先端でエンベロープと結合して いた。 RNP の主要構成ウイルスタンパク質 NPに 対する抗体を用いた免疫電顕法により，これらの $\operatorname{rod}$ RNP であることが確かめられた。続いて出 芽するウイルス粒子の横断面を観察すると, ウイル ス粒子内部には，輪切りにされた RNP が規則的な 配置（中心に 1 本，その周囲に 7 本）で並んでいる 様子が観察された。中には 7 本の RNP を含む粒子 やRNPを 1 本も含まない粒子も観察されたが，1 つのウイルス粒子内に含まれる RNP は最大で 8 本 であり，9本以上の RNP を含むウイルス粒子は観 察されなかつた。今度は，1つのウイルス粒子を頂 点から下に向かって連続的に横断し, ウイルス粒子 内部の RNP 全体の様子を観察した。 ウイルス粒子 の先端を薄切すると，粒子内部には規則的に並ぶ 8 本の RNP が観察された．続いて下方に向かって薄 切していくと，粒子内部に観察される RNP の数は 徐々に減少した。すなわち，ウイルス粒子は 8 本の RNP を取り込んでおり，それらの長さはそれぞれ 異なることが明らかになった（Fig. 1)．RNP の長 さは各 RNA 分節の塩基数に応じて異なることか ら, ${ }^{9)} こ れ ら の$ 観察結果は，規則的な配置に並べら れた異なる種類の 8 本の RNP が，1 つのウイルス 粒子内に取り込まれることを示唆している。本結果 は，電子線トモグラフィーを用いたウイルス粒子内 RNP の立体構造解析によっても確認された. ${ }^{10)} さ$ らに，RNP と RNP の間に核酸様の構造物が認め られたことから，8 種類の遺伝子分節間に特異的な 


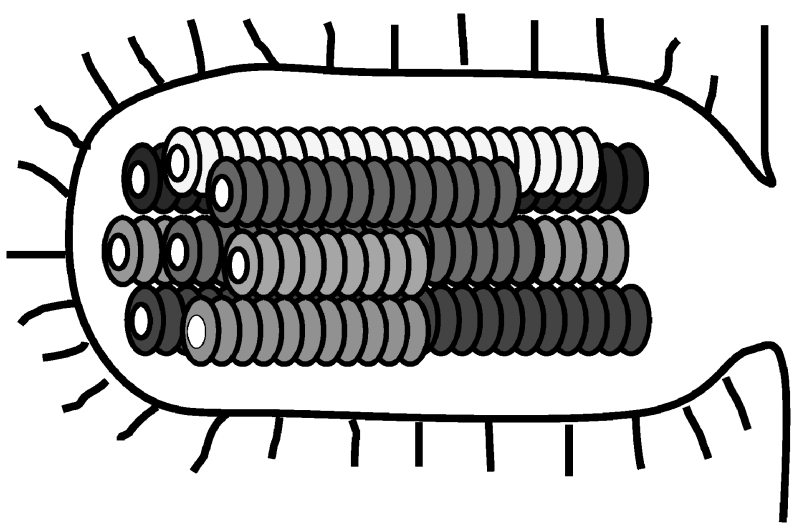

Fig. 1. Schematic Diagram of a Budding Influenza Virion Eight RNPs are arranged in a specific pattern in budding virion, where a central RNP is surrounded by the remaining seven RNPs.

相互作用が存在することも示唆された.

5. おわりに

以上，インフルエンザウイルスのゲノムパッケー ジング機構は, 8 種類 8 本の RNP を 1 セットにま とめてウイルス粒子内に取り込むものと考えられ る.このようなパッケージングメカニズムは，異な る種類の宿主動物（ヒト, ブタ, トリ）から分離さ れたウイルス株でも広く保存されており, ${ }^{8)} \mathrm{A}$ 型イ ンフルエンザウイルスが種を存続させるために共有 する重要なメカニズムであると考えられる。では一 体，どのようなメカニズムで 8 本の RNP がまとま るのか? そのメカニズムの解明は今後の課題とな るが，パッケージングシグナル（例えば，パッケー ジングシグナルを介した RNA-RNA 相互作用など） がRNP の集合に係わっているのではないかと予想 している.

利益相反開示すべき利益相反はない.

\section{REFERENCES}

1) Hirst G. K., Pons M. W., Virology, 56, 620631 (1973).

2) Enami M., Sharma G., Benham C., Palese P., Virology, 185, 291-298 (1991).

3) Neumann G., Watanabe T., Ito H., Yoshida T., Kawaoka Y., Proc. Natl. Acad. Sci. USA, 96, 9345-9350 (1999).

4) Fujii Y., Goto H., Watanabe T., Yoshida T., Kawaoka Y., Proc. Natl. Acad. Sci. USA, 100, 2002-2007 (2003).

5) Watanabe T., Watanabe S., Noda T., Fujii Y., Kawaoka Y., J. Virol., 77, 10575-10583 (2003).

6) Fujii K., Fujii Y., Noda T., Muramoto Y., Takada A., Goto H., Horimoto T., Kawaoka Y., J. Virol., 79, 3766-3774 (2005).

7) Muramoto Y., Takada A., Fujii K., Noda T., Iwatsuki-Horimoto K., Watanabe S., Horimoto T., Kida H., Kawaoka Y., J. Virol., 80, 2318-2325 (2006).

8) Noda T., Sagara H., Yen A., Takada A., Kida H., Cheng R. H., Kawaoka Y., Nature, 439, 490-492 (2006).

9) Compans R. W., Content J., Duesberg P. H., J. Virol., 10, 795-800 (1972).

10) Noda T., Sugita Y., Aoyama K., Hirase A., Kawakami E., Miyazawa A., Sagara H., Kawaoka Y., Nat. Commun., 3, 639 (2012). 